\title{
THE IMPACT OF TRADE ON CHILD LABOR: EVIDENCE FROM SELECTED SAARC AND ASEAN COUNTRIES
}

\author{
Rossazana Ab-Rahim \\ Faculty of Economics and Business, Universiti Malaysia Sarawak, Malaysia \\ (rossazana@gmail.com) \\ Bilal Tariq \\ COMSATS Institute of Information Technology, Pakistan \\ (bilal_tariq8@yahoo.com)
}

\begin{abstract}
Past studies have tended to investigate the relationship between trade and child labor under the traditional trade theories, while assuming that the trade in homogenous goods and the results show inconclusive evidence of a relationship. Hence, it would be interesting to investigate the trade effects of differentiated goods on child labor in the setting of the new trade theory. This study attempts to investigate the trade-induced child labor effects (selection, scale and technique effects) in selected Asian countries over the period from 1999 to 2013. The countries consist of the major South Asian Association for Regional Cooperation (SAARC) countries, namely: Bangladesh, India, Pakistan, Nepal, and Sri Lanka and selected ASEAN countries, namely: Cambodia, Indonesia, the Philippines, and Thailand, where child labor is most common. The results of this study confirm that the total impact of trade on child labor also needs to account for the selection effect, in addition to the scale and technique effects. The findings imply trade liberalization hampers the child labor market in the context of the trade in differentiated goods.
\end{abstract}

Keywords: child labor, trade-induced effects, trade openness, SAARC, ASEAN

JEL Classification: D1, J2, J4

\section{INTRODUCTION}

Lin (2011) found that labor is an integral part of production and is used as a vital factor of production. Due to this influential role, labor costs are considered to be the major element of the production procedure. Cost minimization is a natural wish for producers, but the optimum level of low costs can only be achieved either by using cost efficient technology or by employing low cost factors of production (Bleakley \& Lin, 2012). In developing countries, the producer usually uses labor as a major factor of production (Casson, 2012) and tries to minimize the production costs (Eckel \& Neary, 2010). In a simple economic model, capital and labor are used as a factor of production and there is always substitution between capital and labor to achieve the maximum level of output (Akabayashi \& Psacharopoulos, 1999).
However, in developing countries, labor is valued more due to its cost effective factor of production, as compared to capital and its easy availability (Krugman, 1991). The available labor force can be categorized into skilled and unskilled labor (Bharadwaj, 2014), male and female, as well as adult and child labor (Azmat $\&$ Petrongolo, 2014).

Economies that are taking part in international trade are expanding their potential beyond their domestic borders to reach global markets. In this vein, trade liberalization is now becoming an important aspect of globalization, economic development and sustainability; nevertheless, countries with accelerated growth in their labor intensive sectors are viewed as contributing to the child labor violations (Chan, 2003). Child labor is the employment of children in any work that harms them or keeps them away 
from school. A stream of trade and child labor literature shows that the demand for child labor is associated with the demand for trade goods. One possible reason for the link between trade and child labor is apparent in Edmonds and Pavcnik's (2005) study, which showed that there is a strong and positive association between trade and income. Trade expands the consumption basket and enables the consumers to use both local and imported varieties of goods. At the same time, when the income level of a country increases due to trade openness, the country implements a stricter approach to child labor, which causes an amplified reduction in child labor (Edmonds, 2005; 2015).

Adult labor and child labor are close substitutes (Basu and Van, 1998) and child labor is economical and can be employed in any field of work at a cheaper price, compared to adult labor (Hindman, 2009). But this justification for hiring child labor is not tolerated in civilized and developed countries, because child labor deprives children of the happiness and enjoyment of childhood (Nieboer, 2011). International trade is not free from the effects of child labor (Estevez, 2010), it certainly enhances child labor, so the nature of the trade-induced effects of child labor need to be analyzed in the trading nations. The majority of past studies investigated the effects of child labor on trade by using the traditional trade theories and found mixed evidence in their studies, nevertheless, a consistent body of evidence, primarily from the South Asian region, narrates that trade appears to be a source for the reduction of child labor (Topalova, 2010; Ray, 2000).

On this note, a stream of studies have investigated the relationship between trade and child labor under the traditional trade theories; assuming that the trade in homogenous goods is based on the Stolper-Samson and HeckscherOhlin frameworks (Edmonds \& Pavcnik, 2006b; and Edmonds, 2010). In the homogenous goods framework, the impacts of trade on child labor are ambiguous. One would expect to observe an increase in the incidence of child labor, in line with the increase in the demand for unskilled labor, as a result of trade liberalization
(Edmonds \& Pavcnik, 2005). Since past trade studies have tended to focus on the trade in homogenous goods, the novelty of the present study is the soundness of trade openness and its impact on child labor under the new trade theory framework. On this note, this study departs from previous studies by confining the trade and child labor nexus to the setting of the trade in differentiated goods under the new trade theory framework (Krugman, 1979). The great Krugman developed a tractable approach to model trade using the new assumptions, namely imperfect competition, increasing returns to scale and differentiated goods. Feenstra (2003) added that the increasing returns might be a reason for trade between countries, and a tool for the comparative advantage of nations.

The growing literature on the modern aspects of international trade sheds new light on the effects of the trade in differentiated products, the market's size, and the international division of labor. Along this line, the issue of child labor, in relation to the trade in differentiated products, is noteworthy and worth investigating. Past trade studies suggest that if a country is engaged in the trading of homogeneous goods, an unskilled labor force is demanded, especially in the traditional agricultural sector. As a result, the demand for child labor increases. Another stream of studies, that deliberately diverge from the traditional trade theory, postulate that highly skilled and well-educated workers are required to produce differentiated goods. Therefore, the trade in differentiated goods has resulted in a reduction in the demand for child labor (Estevez \&Levy, 2014).

Several studies have attempted to correlate trade and child labor in the traditional trade theory, but there is a paucity of empirical studies that seek to demonstrate the effects of trade on child labor under the new trade theory. Thus, this study is an attempt to investigate the tradeinduced effects on child labor in the selected South Asian Association for Regional Cooperation (SAARC) and Association of South East Asian Nations (ASEAN) countries by applying the new trade theory. The selected SAARC countries are Bangladesh, India, 
Pakistan, Nepal, and Sri Lanka while the ASEAN countries consist of Cambodia, Indonesia, the Philippines, and Thailand. The question that arises is why SAARC and ASEAN? There are many reasons for the selection of these regions, but the most important is that SAARC and ASEAN are two pivotal regional platforms for economic cooperation in Asia. Accelerating population growth rates, rural to urban migration and globalization are major factors contributing to child labor in the SAARC and ASEAN regions, and the sensitivity of the topic of child rights makes it a priority issue, demanding immediate attention. Concerns have been raised regarding the structure and process of trade liberalization that can affect child labor. Hence, the main research question for this study is: Does trade hamper child labor in selected Asian countries under the new trade theory framework?

The first contribution of the present study is that it addresses the trade-induced effects, based on Krugman's framework (1979). This study offers an empirical effort to explore the relationship between child labor and trade for the selected SAARC and ASEAN countries that are engaged in the trading of both differentiated and homogeneous goods, as well as examining the effects of trade intensity on child labor. The second contribution of this study is that it disentangles the various new channels through which trade openness affects child labor, via the trade-induced scale effect, selection and technique effects. Feenstra (2003) determined the trade-induced effects for firms that are engaged in the production of differentiated products; the effects are decomposed to the selection and scale effects. The former refers to the exit of the least efficient firms due to liberalization; as a result, the average for industries' productivity increases. The latter effect refers to the change in the scale of the economy, holding all other things constant.

This study is important because of its attempt to provide empirical evidence on the effects of the trading of differentiated products on child labor, and the significance of controlling child labor using the selection effect.
It is hoped that this study will contribute to the limited evidence on child labor and the new trade theory, and offer recommendations to policymakers in promoting trade among developing countries, specifically in the SAARC and ASEAN regions, in order to combat child labor. Simultaneously, the results of this study offer support to human rights activists who fight to eliminate child labor. The next section discusses the background and previous work in this area, and the section following it provides an empirical background and describes the data used in this study. That section is then followed by the relevant results and the last section discusses viable policy recommendations and future study directions.

\section{PAST STUDIES}

The emergence of monopolistic competitive firms in developing countries has created the demand for educated and skilled workers, making it possible to create integrated production systems spanning more than one country. Economies that are taking part in international trade are expanding their potential beyond their domestic borders to reach global markets. Trade liberalization is becoming an important aspect of globalization, economic development and sustainability. Nevertheless, countries with accelerated rates of growth in their labor-intensive sectors are viewed as contributing to child labor violations (Estevez, 2010).

Along with this development, Estevez (2010) claims that firms usually use both unskilled and skilled labor in the production of differentiated goods. The complementary effect increases the skills premium and changes the demand for unskilled labor, which indirectly affects the demand for child labor. Estevez and Levy (2014) also examined the effect of the demand for lowand high-skilled workers, and the choices made by firms to upgrade their production techniques. Since the advancement in production techniques is biased toward skilled workers, there is less demand for unskilled and/or child labor in the production of differentiated goods. Estevez (2011) therefore concludes that child labor is not 
preferred after allowing for productivity differences. Estevez and Levy (2014) assumed that in the production of differentiated goods, child labor is not an option because productivity differences make it expensive for the producers.

According to the new trade theory, the trade in differentiated products tends to be prevalent among countries that are similar in their factor endowments, technology, skill levels, and so on. Thus, the trade in differentiated products will be the dominant trade pattern, especially between countries with a similar level of economic development. It has been established that large gains from trade will be made when the economies of scale are strong and trade goods are highly differentiated (Krugman, 1980). On this note, product differentiation and economies of scale form the basis of the trade in differentiated products. The role of unskilled labor is also very important in trade, and is relevant to the framework based on the new trade theory, as advanced by Egger et al. (2007). The authors built a two-country model of skilled and unskilled labor, which assumes monopolistic competition. The framework examines the effects of the trade in intermediate products on unskilled labor, output levels and welfare, under the conditions of the endogenous tax and skilled to unskilled labor's functions. The framework provides interesting insights into the effects of the trading of intermediate goods on the level of foreign unskilled labor.

Based on Krugman's (1979) framework for international trade, Figure 1 shows that the industrial sector experiences the increasing returns to scale ${ }^{1}$ as a result of trade liberalization. However, the total number of firms in the industry shrinks, although the production of each of the incumbent firms increases due to trade openness (Chen et al., 2002). Trade expands the consumption basket and enables the consumers to use both local and imported varieties of goods. At the same time, when the income level of a country increases due to trade openness; the country implements a stricter approach to child labor, which causes an

\footnotetext{
1 Returns to scale refers to reduction in cost per unit resulting from increased production (Balassa, 2013).
}

amplified reduction in child labor activities (Edmonds, 2007). The increasing returns to scale in Krugman's framework compel producers to hire more efficient and skilled labor, to raise their production levels. This framework has the potential to support child labor elimination policies and discourage child labor, because producers want to produce more, and additional units of adult labor are not expensive for them due to their increasing returns to scale. In this framework, there is a selection on the production side and the consumption side. The producer selects the best available labor for the production process (Miles et al., 1978) and the consumer has the option to select between a variety of differentiated products (Krugman \& Venables, 1996).

Based on the preceding discussion of past studies in this area, this study proposes the following hypotheses for the trade-child labor relationship, which describe the impacts of both the trade in differentiated and homogeneous goods on child labor.

\section{Hypothesis 1: Child labor decreases with a decrease in the number of firms, or a positive trade-induced child labor selection effect.}

The fall in the number of varieties of domestic products leads to the exit of unprofitable firms. Hence, everything else being equal, openness to trade implies a fall in the number of firms, which leads to a fall in child labor numbers. In other words, child labor decreases along with the decrease in the number of firms, ceteris paribus.

Hypothesis 2: Child labor increases along with an increase in the scale of production, or a positive tradeinduced child labor scale effect.

Consider an economy with a labor-intensive sector that produces differentiated goods. The production of differentiated goods corroborates that the scale of economic activities determines the need for child labor in the economy. Given new technology, an increase (decrease) in the scale of labor-intensive industries leads to an increase (decrease) in the labor demand 


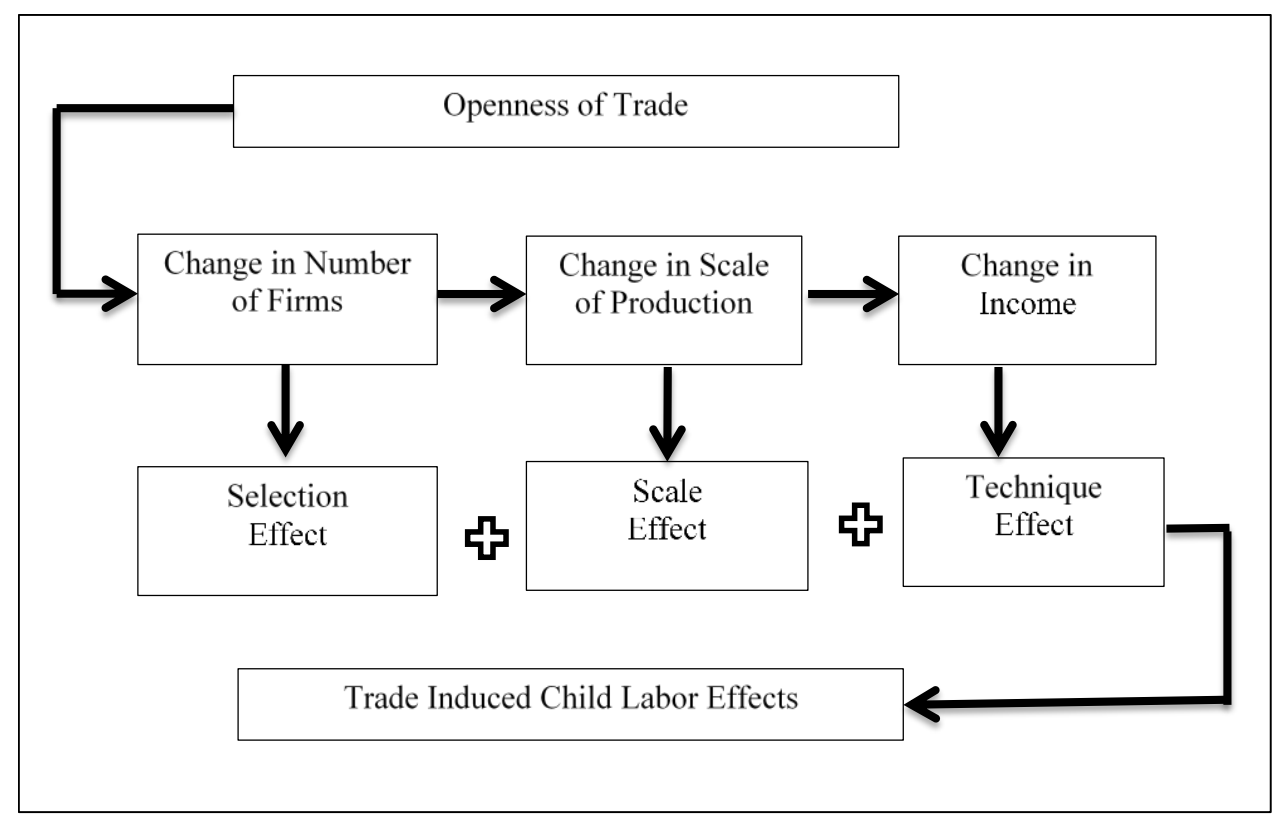

Source: Adapted from Feenstra (2003)

Figure 1.Trade-Induced Child Labor Effects

(Hamermesh, 1987), and child labor is a substitute for adult labor, and is parsimonious compared to adult labor (Basu \& Tzannatos, 2003); so any increase (decrease) in the labor demand leads to an increase (decrease) in the demand for child labor.

\section{Hypothesis 3: Child labor is negatively associated with income levels due to changes in trade intensity, or the negative trade-induced child labor technique effect.}

Holding the scale effect and other determinants constant, the technique effect refers to the turnabout in child labor as a result of adjustments to income levels, due to trade's intensity (Edmonds, 2005; 2015).

Hypothesis 4: Child labor decreases with an increase in trade intensity or the openness to trade.

The openness to trade may accelerate an inward flow or diffusion of more efficient techniques, which reduces child labor's intensity. Therefore, holding other factors constant, greater openness to trade leads to a negative growth in child labor (Edmonds, 2005; 2015).

Table 1. Trade-Induced Child Labor Effects

\begin{tabular}{ll}
\hline Trade-induced Effects & \multicolumn{1}{c}{ Explanation } \\
\hline Selection Effects & $\begin{array}{l}\text { Holding scale and technique effects constant, a change in trade intensity leads to a } \\
\text { change in the number of domestic firms, which results in a trade-induced child } \\
\text { labor selection effect. } \\
\text { Holding all other factors constant, a change in the growth of the economy due to } \\
\text { trade liberalization yields a trade-induced child labor scale effect. }\end{array}$ \\
Technique Effect & $\begin{array}{l}\text { Holding other factors equal, a change in the income growth of an economy due to } \\
\text { trade liberalization leads to a trade-induced child labor technique effect. } \\
\text { The total impact of trade on child labor depends upon the sum of the magnitude } \\
\text { of trade-induced child labor's selection, scale and technique effects. }\end{array}$ \\
\hline
\end{tabular}




\section{METHODOLOGY}

This study examines child labor in selected SAARC (Bangladesh, India, Pakistan, Nepal, and Sri Lanka) and ASEAN (Cambodia, Indonesia, the Philippines, and Thailand) countries over the period from 1993 to 2013. ${ }^{2}$ This study targets children aged between 5 to 14 years old, engaged in economic activities, as a percentage of the country's population from various data sources. Most of the countries have some independent observations for a given year; some observations are taken by imputation rather than actual variations in child labor rates, due to infrequent surveys, generally in the SAARC countries. The intertemporal variations in child labor data are driven by imputation and adjustments based on country-wide household surveys at the national level. ${ }^{3}$ For controlling the time invariant country characteristics, a panel data is recommended. The panel data allows for the dynamics of an individual country's behavior, as compared to a cross section assortment at one specific point in time. Panel data analysis also allows consistent estimates for

\footnotetext{
2 The main constraint of undertaking studies on child labor is due to the limitations of the data. The international organizations such as the World Bank (WB), International Labour Organization (ILO), and Understanding Children's Work (UCW) do provide reliable data on child labor in the developing countries; however, the big challenge for this study was to gather data for child labor and the number of listed companies' variables. This data limitation problem is also encountered by prominent scholars working on similar grounds, such as Edmonds and Pavcnik (2006a), Neumayer and De Soysa (2005), and Acaroglu and Dagdemir (2010). Hence, this study confines its analysis to covering five SAARC countries and four ASEAN countries. It is noteworthy that data on child labor in other economies such as Bhutan and Myanmar is difficult to obtain, due to the government regulations categorizing child labor data as 'highly confidential' (Hindman, 2009).

${ }^{3}$ Most of the countries have some independent observations for given years. Some observations are taken by imputation rather than actual variations in child labor figures due to infrequent surveys, generally in the lowincome countries. For controlling the time invariant country characteristics, this study employs a panel data analysis; following closely the works of Neumayer and De Soysa (2005), Acaroglu and Dagdemir (2010), and Estevez (2011).
}

a fixed effects model; in conjunction with this consistency, unobserved country specific heterogeneity, which sometimes correlates with regressors, can be resolved in a fixed effects model.

The theoretical links between trade and child labor are presented in the following empirical specification: Model-A shows the change or growth in total child labor rates decomposed into the respective scale, selection and technique effects. The model expresses the demand for child labor in an autarky situation with respect to time $(t)$ across the countries.

$$
\begin{aligned}
\varsigma l_{i t}= & \alpha_{0}+\alpha_{1} S C L_{i t}+\alpha_{2} S E L_{i t}+ \\
& \alpha_{3} T E C_{i t}+u_{i t}
\end{aligned}
$$

Child labor $s l_{i t}$ is defined as children under the age of 14 who engage in any economic activities. Theoretically, the number of firms is directly associated with the demand for labor (Brainard \& Riker, 1997; Fehr et al.,1998; Felbermayr \& Prat, 2011) and child labor is also directly linked to the demand for labor (Humphries, 2010).

The selection effect $S E L_{i t}$ shows the effect of a change in the number of firms on child labor, based on the selection of product variety 4 and it is associated with the country-specific number of listed companies. On this note, product variety can best be defined as firm-level production, that is, the number of firms engaged in the production of differentiated products. This study uses the number of listed domestic companies to represent the selection effect, sourced from the World Development Indicators (WDI).

The data used for the scale effect can be minimal or extensive, depending on the level of accuracy. However, it should complement the aggregate effects of the changes in child labor in

\footnotetext{
${ }^{4}$ The selection effect can be represented by two measures; firstly, by the change in the product varieties produced domestically (Tariq \& Ab-Rahim, 2016); secondly, by the change in the number of domestic firms. In a current analysis, change in the preference of variety is explained by the number of firms (Feenstra, 2003). Consistent with other measures, the measure of the number of firms is in its intensive form and it is the number of listed domestic companies per square kilometer (companies $/ \mathrm{km}^{2}$ ).
} 
the setting of both the homogeneous and differentiated goods. Mukhopadhyay and Chakraborty (2005) and Copeland and Taylor (2001) suggest that scale and technique effects can be represented by Gross Domestic Product (GDP) and Gross National Product (GNP), respectively. The scale effect is proxied by GDP per kilometer square, because there are notable differences in the GDPs of the SAARC and ASEAN countries, this can avoid the pragmatic approach to evaluating the impact of the effects of scale.

The technique effect is the improvement in child labor numbers as firms undertake the amelioration of their labor force to meet labor regulation standards; the higher the income, the more stringent the child labor regulations will be. Thus, the change in child labor can be represented by the change in the techniques of production (Karlan \& Valdivia, 2011), where an increase in income levels is associated with a decrease in child labor rates.

This difference between GDP and GNP, which is the Net Foreign Factor Income (NFFI), is also utilized in this study. In other words, NFFI refers to the difference between payments given to home country labor from foreign people, and payments given to foreign country labor from home country people. In fact, this technique is more appropriate in Krugman's framework, because labor is treated as the key factor of production in that setting. Hence, a country that has more skilled labor takes more income from foreign countries, as more skilled labor will use better techniques.

It is noteworthy that Model-A does not express the effect of trade liberalization. Thus, the trade variable $T R_{i t}$ is used to examine the effect of the overall trade on the level of child labor in Model-B. $T R_{i t}$ is defined as the openness of trade, in terms of the trade intensity, and calculated as the ratio of imports plus exports to GDP $\left(\frac{(X+M)}{G D P}\right)_{i t}$. The greater the share of trade in the GDP, the greater is the trade intensity of a country, and the more open the economy is to foreign competition. The use of trade intensity is very common. Fung and
Maechler (2007), Alam et al. (2011), and Tariq and Ab-Rahim (2016) utilized this variable to express trade liberalization. Having said that, trade intensity is used to measure two effects; the link between trade liberalization and child labor, and the interaction formed to express the responses to the trade-induced selection effect, scale, and the technique effects. So, Model-A can be rewritten as:

$$
\begin{gathered}
\varsigma l_{i t}=\alpha_{0}+\alpha_{1} S C L_{i t}+\alpha_{2} S E L_{i t}+ \\
\alpha_{3} T E C_{i t}+\alpha_{4} T R_{i t}+u_{i t}
\end{gathered}
$$

Model-B only shows the effects of the selection of product variety, scale of production, technique of production, and trade on child labor. Hence, to derive trade-related child labor effects, an interaction term $T R_{i t}$ is introduced in Model-C, which is known as the trade-induced child labor effects:

$$
\begin{aligned}
s l_{i t}= & \alpha_{0}+\alpha_{1} \text { SELTR }_{i t}+\alpha_{2} \text { SCATR }_{i t}+ \\
& \alpha_{3} \text { TECTR }_{i t}+u_{i t}
\end{aligned}
$$

The variable $S E L T R_{i t}$ shows the change that trade brings in terms of the number of firms; trade hampers the number of firms due to the economies of scale and as a result, a country may specialize in the production of a limited range of products. The effect of a change in the number of firms on the level of child labor, as a result of the change in trade intensity, is called the trade-induced child labor selection effect $\left(\operatorname{SELTR}_{i t}\right)$; this variable is measured by the number of domestic companies per square kilometer along with the openness of trade.

The variable $S C L T R_{i t}$ represents the change in the scale of production due to the change in trade intensity, which is measured by the $i_{t h}$ country's gross domestic product per square kilometer interacted with trade intensity (tradeinduced child labor scale effect) at time $t$. To find the trade-induced child labor technique effect, NFFI per capita is interacted with trade intensity $(T E C T R)_{i t}$. Copeland and Taylor (2001) used this trade-induced technique effect in their work on trade and the environment. Descriptions of all the variables used in this study are shown in Table 2. 
Table 2. Description of Variables

Dependent Variable

\begin{tabular}{|c|c|c|}
\hline Variable Name & Code & Variable Explanation \\
\hline Child Labor & $\varsigma_{\text {it }}$ & Percentage of children (aged 5-14) engaged in child labor \\
\hline Data Source & & $\begin{array}{l}\text { Data are gathered by accessing specific databases, i.e. ILO (IPEC } \\
\text { reports), The United Nations Children's Fund (UNICEF), } \\
\text { Understanding Children's Work (UCW), and the Department of } \\
\text { Census \& Statistics from different countries, and the World } \\
\text { Development Indicators etc. A comprehensive internet search } \\
\text { and e-mails to key informants were also made to collect the } \\
\text { related child labor data. }\end{array}$ \\
\hline
\end{tabular}

Independent Variables

\begin{tabular}{lcl}
\hline Selection Effect & $S E L_{i t}$ & $\begin{array}{l}\text { Country specific number of listed companies per squared } \\
\text { kilometer. }\end{array}$ \\
Scale Effect & $S C L_{i t}$ & $\begin{array}{l}\text { Gross Domestic Product (GDP) per squared kilometer } \\
\text { Technique Effect }\end{array}$ \\
Trade & $T E C_{i t}$ & Net Foreign Factor Income (NFFI) per capita \\
Trade-induced Technique Effect & $T E C T R_{i t}$ & Import plus export ratio to GDP \\
Trade-induced Selection Effect & $S E L T R_{i t}$ & Selection effect interacted with the openness of trade \\
Trade-induced Scale Effect & $S C L T R_{i t}$ & Scale effect interacted with the openness of trade \\
\hline
\end{tabular}
Note: Data for independent variables are derived from the World Development Indicators

Unobservable parameters such as the exogenous demographic attributes, labor market attachments, education system and child labor preference in the production process (as a complement or substitute) can be considered as time-invariant country-specific effects represented by the unobserved heterogeneity, denoted by $\varepsilon_{i}$. It is also noted that common-toall-countries effects such as relative income idiosyncrasies, unconventionalities in the amelioration process and dynamic technological improvements may be considered as timespecific effects, denoted by $\beth_{t}$. Machine errors in reading the concentrations of child labor and human error in the calculations are sources of idiosyncratic errors represented by $\mu_{i t}$. The unobservable and individual effects of the model are specified in the following way:

$$
u_{i t}+\varepsilon_{i}+\beth_{t}+v_{i t}
$$

$\beth_{t}$ is a time-specific effect, $\varepsilon_{i}$ is a countryspecific effect, and $v_{i t}$ is an idiosyncratic measurement error for a country at time $t$. The most familiar fixed effects and random effects panel data treatments for count data are suggested by Hausman et al. (1984). If country- specific effects contained in the unobserved random component, which may be the case in many practical applications in international economics, are correlated with predictors, the fixed effects estimator will allow for consistent estimations of the model. In contrast to the fixed effects model, the unobserved country-specific heterogeneity is sometimes distributed randomly by the predictors. In this case, consistent and efficient estimations are contingent upon the model of the random effects estimator. Note that the pooled Ordinary Least Squares (OLS) estimator is inconsistent if the true model is the fixed effect model.

\section{EMPIRICAL RESULTS AND DISCUSSION}

\section{Descriptive Statistics}

The analysis is carried out using panel data models over the period from 1999 to 2013 in selected ASEAN and major SAARC countries. Panel data allows the dynamics of an individual country's behavior to be compared to a crosssection assortment at a specific point in time. Panel data analysis also allows consistent estimates for a fixed effects model, in conjunc- 
tion with consistency and unobserved countryspecific heterogeneity, which sometimes, when correlated with regressors, can be resolved in a fixed effects model. However, if unobserved country-specific effects are assumed to be distributed randomly of the regressors, the random effects model implies additional orthogonality. In order to ensure a valid statistical inference, the panel-robust statistical inferences are corrected for both the correlation of errors over time and heteroscedasticity across the major SAARC and selected ASEAN countries. The Hausman specification test is used to check whether a fixed or random effects model is more appropriate. The descriptive statistics of the variables employed in this study are reported in Table 3. The summary statistics provide useful information on child labor and other explanatory variables by performing empirical analyses in 9 countries (the major SAARC countries, namely Bangladesh, India, Pakistan, Nepal, and Sri Lanka, and selected ASEAN countries, namely Cambodia, Indonesia, the Philippines, and Thailand). This study uses 15 years of annual data from 1999 to 2013, with a total number of 135 observations.

Based on Table 3, the selection effect (number of listed companies $/ \mathrm{km}^{2}$ ) varies from $7.18 \mathrm{e}^{-05}$ points to $4.37 \mathrm{e}^{-03}$ points, while the technique effect (NFFI per capita) varies from 0.26 points to 178.62 points and the scale of the countries $\left(\mathrm{GDP} / \mathrm{km}^{2}\right)$ varies from a low of 753 to a high of 8,730 with a mean of 3,660 . The explanatory variable trade changes between $25.54 \%$ to $150.32 \%$ with a mean of $70.45 \%$, which implies that some economies are more open to trade than others, the trade-induced selection effect variable has a minimum of 82.2 and a maximum of 707 with a mean of 1,260 , while the average of the trade-induced scale and technique effects are 246,000 and 2,360 respectively. The mean of the unemployment and literacy rate indices are $4.78 \%$ and $71.32 \%$, respectively.

The estimation procedure of this study consists of three steps. In the first step, an exposure assessment of the simple model was done by capturing the selection, scale and technique effects obtained for child labor in SAARC and ASEAN respectively, in the case of a closed economy. In the second step, the variable of trade was combined with the selection, scale and technique effects variables in both regions, to find the effect of a change in trade on child labor. Finally, the open economy model investigated the relationship between these variables and child labor in different combinations of SAARC and ASEAN countries.

Table 3. Descriptive Statistics of Variables

\begin{tabular}{|c|c|c|c|c|c|}
\hline Variable Name & Code & Mean & Max & Min & Std. Dev. \\
\hline Child Labor & $\zeta \mathrm{l}_{\mathrm{it}}$ & 15.91 & 52.3 & 1.47 & 14.47 \\
\hline Selection Effect & $S E L_{i t}$ & $1.21 \mathrm{e}^{-03}$ & $4.37 \mathrm{e}^{-03}$ & $7.18 \mathrm{e}^{-05}$ & $1.04 \mathrm{e}^{-03}$ \\
\hline Scale Effect & $S C L_{i t}$ & $3.66 \mathrm{e}^{+03}$ & $8.73 \mathrm{e}^{+03}$ & $7.53 \mathrm{e}^{+02}$ & $1.71 \mathrm{e}+05$ \\
\hline Technique Effect & $T E C_{i t}$ & 67.97 & 178.62 & 0.26 & 24.87 \\
\hline Trade & $T R_{i t}$ & 70.45 & 150.32 & 25.54 & 36.76 \\
\hline Trade-induced Technique Effect & TECTR $_{i t}$ & $2.36 \mathrm{e}^{+03}$ & $6.44 \mathrm{e}^{+03}$ & $2.14 \mathrm{e}^{+02}$ & $1.61 \mathrm{e}^{+03}$ \\
\hline Trade-induced Selection Effect & $S E L T R_{i t}$ & $1.26 \mathrm{e}^{+02}$ & $7.07 \mathrm{e}^{+02}$ & $8.22 \mathrm{e}^{+01}$ & $1.59 \mathrm{e}^{+02}$ \\
\hline Trade-induced Scale Effect & $\operatorname{SCLTR}_{i t}$ & $2.46 \mathrm{e}^{+05}$ & $6.64 \mathrm{e}^{+05}$ & $2.04 \mathrm{e}^{+04}$ & $1.71 \mathrm{e}^{+05}$ \\
\hline Unemployment $^{5}$ & $U N E P_{i t}$ & 4.78 & 11.9 & 0.2 & 2.89 \\
\hline Literacy Rate ${ }^{6}$ & $E D U_{i t}$ & 71.32 & 97.23 & 32.57 & 20.27 \\
\hline
\end{tabular}

\footnotetext{
${ }^{5}$ Labour force that is without work but available for and seeking employment.

${ }^{6}$ Percentage of the population aged 15 and above, who can read and write.
} 
Table 4. Estimation Results for Model A and Model B (Fixed Effect Model)

\begin{tabular}{|c|c|c|c|c|c|c|}
\hline & \multicolumn{3}{|c|}{ Model A (Closed Economy) } & \multicolumn{3}{|c|}{ Model B (Open Economy) } \\
\hline & ASEAN & SAARC & $\begin{array}{c}\text { SAARC } \\
\& \text { ASEAN }\end{array}$ & ASEAN & SAARC & $\begin{array}{l}\text { SAARC } \\
\text { \& ASEAN }\end{array}$ \\
\hline SEL & $\begin{array}{l}-0.025 \\
(1.34)\end{array}$ & $\begin{array}{l}-0.002 \\
(-1.03)\end{array}$ & $\begin{array}{c}-0.007 * * * \\
(-3.21)\end{array}$ & $\begin{array}{c}-0.036 * \\
(-1.88)\end{array}$ & $\begin{array}{c}-0.007 * * * \\
(-8.68)\end{array}$ & $\begin{array}{c}-0.0197 * \\
(-1.69)\end{array}$ \\
\hline TEC & $\begin{array}{c}-0.004 \\
(0.75)\end{array}$ & $\begin{array}{c}-0.001 * * * \\
(-2.90)\end{array}$ & $\begin{array}{c}-0.0008^{*} \\
(-1.79)\end{array}$ & $\begin{array}{c}0.010 \\
(0.541)\end{array}$ & $\begin{array}{c}-0.005 * * * \\
(-8.28)\end{array}$ & $\begin{array}{c}0.0001 * \\
(1.75)\end{array}$ \\
\hline SCL & $\begin{array}{c}0.010 * * * \\
(4.01)\end{array}$ & $\begin{array}{c}0.0039 * * * \\
(5.65)\end{array}$ & $\begin{array}{c}0.0062 * * * \\
(7.56)\end{array}$ & $\begin{array}{c}0.10^{* * *} * \\
(6.19)\end{array}$ & $\begin{array}{c}0.008 * * * \\
(8.30)\end{array}$ & $\begin{array}{c}-0.0004 * * * \\
(-3.33)\end{array}$ \\
\hline TRADE & - & - & - & $\begin{array}{c}0.108 * * \\
(1.97)\end{array}$ & $\begin{array}{c}0.510 * * * \\
(4.91)\end{array}$ & $\begin{array}{c}0.013 \\
(0.26)\end{array}$ \\
\hline Hausman & $\begin{array}{l}33.16 \\
(0.00)\end{array}$ & $\begin{array}{c}0.73 \\
(0.000)\end{array}$ & $\begin{array}{c}6.96 \\
(0.073)\end{array}$ & $\begin{array}{c}32.89 \\
(0.000)\end{array}$ & $\begin{array}{c}65.01 \\
(0.000)\end{array}$ & $\begin{array}{c}3.911 \\
(0.418)\end{array}$ \\
\hline $\begin{array}{r}\text { Observations } \\
\mathrm{R}^{2}\end{array}$ & $\begin{array}{c}60 \\
0.043\end{array}$ & $\begin{array}{c}75 \\
0.280\end{array}$ & $\begin{array}{c}135 \\
0.295\end{array}$ & $\begin{array}{c}60 \\
0.009\end{array}$ & $\begin{array}{c}75 \\
0.287\end{array}$ & $\begin{array}{c}135 \\
0.298\end{array}$ \\
\hline
\end{tabular}

Note: $\varsigma l_{i t}=\alpha_{0}+\alpha_{1} S E L_{i t}+\alpha_{2} S C L_{i t}+\alpha_{3} T E C_{i t}+u_{i t} \ldots$ (A)

$\zeta l_{i t}=\alpha_{0}+\alpha_{1} S E L_{i t}+\alpha_{2} S C L_{i t}+\alpha_{3}$ TEC $_{i t}+\alpha_{4}$ Trade $_{i t}+u_{i t} \ldots$ (B)

$* * *, * *, *$ significance at $1 \%, 5 \%$ and $10 \%$

Table 4 presents the initial estimates of the impact of the selection, scale and technique effects of Model A for autarky and Model B for an open economy, by assuming that the relative position of the selected ASEAN and SAARC countries remains constant, during either labor amelioration or population growth. Based on the results of Model A, the scale effect is consistent with a positive sign in both regions; while in Model $\mathrm{B}$, the sign is surprisingly negative but at a very small magnitude when measuring SAARC and ASEAN together. So, the overall scale effect variable on child labor is positive.

The theory predicts that at high-income levels, countries have better techniques of production, which hampers labor accumulation, as development persists as well as a significant reduction in child labor as empirically shown in Model A. However, this prediction is only valid for SAARC countries in Model A.

Finally, the selection effect indicates a negative relationship between the number of listed companies and child labor. The paradoxical results of the selection effect implies that a reduction in the number of competent firms engaged in the production of differentiated goods can increase child labor, and an increase in the number of competent firms can cause a reduction of child labor in both the SAARC and ASEAN countries.

Another variable of interest, the trade variable, suggests that an increase in the trade to GDP ratio raises child labor rates, which could be explained by the labor-intensive production techniques in the major SAARC and selected ASEAN countries. Labor-intensive production is also a reason for an increase in child labor in these countries. Relatively simple hypotheses regarding the effect of international trade on child labor are investigated by adding measures of the openness of trade. Some estimates of the scale and technique effects variables are suppressed, because the inclusion of the trade variable had little impact on the other estimates, as reported in Table 4. Theoretically, there is a negative relationship between trade and child labor. Nevertheless, the results of this study show that there appears to be a positive relationship between trade and child labor. Past studies, such as those by Busse and Wittwer (2001), and Neumayer and De Soysa (2005) support that trade openness can be a cause of high child labor numbers in developing countries. 
Table 5. Estimation Results for Interacted and Non-interacted Models

\begin{tabular}{|c|c|c|c|c|c|c|}
\hline & \multicolumn{3}{|c|}{ Model A (Non-interacted) } & \multicolumn{3}{|c|}{ Model C (Interacted) } \\
\hline & ASEAN & SAARC & $\begin{array}{c}\text { SAARC \& } \\
\text { ASEAN }\end{array}$ & ASEAN & SAARC & $\begin{array}{c}\text { SAARC \& } \\
\text { ASEAN }\end{array}$ \\
\hline SEL & $\begin{array}{l}-0.025 \\
(1.34)\end{array}$ & $\begin{array}{l}-0.002 \\
(-1.03)\end{array}$ & $\begin{array}{c}-0.007 * * * \\
(-3.21)\end{array}$ & - & - & - \\
\hline SELTR & - & - & - & $\begin{array}{c}0.423 \\
(0.972)\end{array}$ & $\begin{array}{c}2.29 \\
(0.149)\end{array}$ & $\begin{array}{c}-0.0174 \\
(-0.77)\end{array}$ \\
\hline TEC & $\begin{array}{l}-0.004 \\
(0.75)\end{array}$ & $\begin{array}{c}-0.001 * * * \\
(-2.90)\end{array}$ & $\begin{array}{c}-0.0008^{*} \\
(-1.79)\end{array}$ & 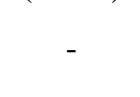 & 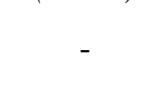 & 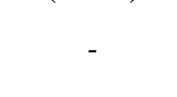 \\
\hline TECTR & - & - & - & $\begin{array}{c}-0.012 \\
(0.640)\end{array}$ & $\begin{array}{c}-0.002 * * * \\
(-6.53)\end{array}$ & $\begin{array}{c}0.00005^{*} \\
(1.86)\end{array}$ \\
\hline SCL & $\begin{array}{c}0.010 * * * \\
(4.01)\end{array}$ & $\begin{array}{c}0.0039 * * * \\
(5.65)\end{array}$ & $\begin{array}{c}0.0062^{* * * *} \\
(7.56)\end{array}$ & 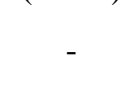 & 1 & - \\
\hline SCLTR & - & - & - & $\begin{array}{l}-0.0017 \\
(-0.69)\end{array}$ & $\begin{array}{l}-0.111^{*} \\
(-1.74)\end{array}$ & $\begin{array}{c}-0.0004 * * * \\
(-3.44)\end{array}$ \\
\hline Hausman Test & $\begin{array}{c}33.16 \\
(0.000)\end{array}$ & $\begin{array}{c}0.73 \\
(0.000)\end{array}$ & $\begin{array}{c}6.96 \\
(0.073)\end{array}$ & $\begin{array}{c}45.47 \\
(0.000)\end{array}$ & $\begin{array}{c}1.52 \\
(0.678)\end{array}$ & $\begin{array}{c}0.14 \\
(0.86)\end{array}$ \\
\hline $\begin{array}{l}\text { Observations } \\
\mathrm{R}^{2}\end{array}$ & $\begin{array}{c}60 \\
0.04\end{array}$ & $\begin{array}{c}75 \\
0.28\end{array}$ & $\begin{array}{l}135 \\
0.38\end{array}$ & $\begin{array}{c}60 \\
0.08\end{array}$ & $\begin{array}{c}75 \\
0.23\end{array}$ & $\begin{array}{l}135 \\
0.34\end{array}$ \\
\hline
\end{tabular}

Table 5 presents the results of trade-induced child labor effects. It is shown that the tradeinduced child labor technique effect increases child labor in the SAARC and ASEAN countries. Further investigation reveals that tradeinduced child labor in the SAARC countries is negative with respect to child labor, while in both the SAARC and ASEAN countries child labor increases due to the technique effect. The linear interaction term of the trade-induced technique effect is positive in both the SAARC and ASEAN countries, and while in a separate setting for these regions, it has a negative association. Consequently, if a country has a relatively low level of production skills and techniques, relative to the rest of the world, then keeping all else constant, the impact of further openness can make these countries vulnerable to increased child labor rates. Therefore, if a country has sufficient skilled labor and better techniques of production, relative to the rest of the world, the impact of the trade-induced child labor technique effect can make the country a safer place for children.

The results of this study offer support to the trade-induced child labor effects namely, the selection, scale and techniques in a noninteracted form. The signs of the selection, scale and technique effects are plausible because in most cases, the signs of these trade-induced effects lead to a reduction in child labor. Neutral technological progress increases the scale of production (Solow, 1956) and creates a positive trade-induced scale effect. According to the results, the scale effect is offset by a negative trade-induced child labor scale effect. The results imply that free trade is more likely to be good rather than bad for child labor.

\section{Robustness of Results}

There are two notable features of the results of the analysis. First, the F-test statistics confirm that at the $1 \%$ level of significance, there is sufficient evidence against the null hypothesis that the difference in cross-country variances is not zero; the results validate the existence of a country-specific effect, therefore, pooled ordinary least squares estimates are inappropriate for this analysis. In addition, the scale, selection and technique effects are interacted with the trade intensity variable, so the coefficient estimates of the scale and technique effects are measured 
from the average trading country. In other words, this is a normal trading country, a country whose trade intensity is equal to the sample mean value.

It is important to note that statistically significant coefficient estimates are derived by excluding Cambodia and Nepal. Without Cambodia and Nepal, the selection effect is positive and consistent with the theoretically predicted strategy that a decrease (increase) in the number of firms leads to a decrease (increase) in child labor. These estimates are statistically significant for the selection effect variables that vary greatly in magnitude and direction in columns 2, 3 and 4 of Table 6 . The results suggest that the fixed effects model is more appropriate because unobserved countryspecific heterogeneity is associated with the predictors. The interesting finding is that the statistically insignificant coefficients are obtained by excluding India and Indonesia from a given data set.

With respect to the selection variable, the results show that the number of firms is positively linked to child labor. The result of the scale effect is contrary to the theoretical prediction that an increase in the scale of production increases the demand for child labor. The negative link between scale and child labor is useful in combatting child labor, as the increase in the scale of production under Krugman's framework is beneficial, due to the demand for skilled labor in the economy.

In the context of the technique effect, the findings suggest that there is a negative association between the technique effect and child labor. The trade variable, on the other hand, has an unexpected significant positive sign. This could result from a non-distinction between the trade in differentiated goods and the trading of homogeneous goods, and similar results have been reported by Kis-Katos (2006). The author concludes that the real income effect of trade can also increase the aggregate child labor and the impact of trade on child labor depends on the techniques of production with a change in income levels across countries.

Table 6. Robustness of the Results

\begin{tabular}{|c|c|c|c|c|}
\hline & (1) & (2) & (3) & (4) \\
\hline SEL & $\begin{array}{c}0.2078 * * * \\
(3.92)\end{array}$ & $\begin{array}{c}0.0057 \\
(0.10)\end{array}$ & $\begin{array}{l}2.014 \\
(0.61)\end{array}$ & $\begin{array}{c}-0.0197 * \\
(-1.69)\end{array}$ \\
\hline TEC & $\begin{array}{c}-0.0001 * * * \\
(-2.90)\end{array}$ & $\begin{array}{c}0.0001 * \\
(1.90)\end{array}$ & $\begin{array}{c}0.0001 \\
(0.99)\end{array}$ & $\begin{array}{c}0.0001 * \\
(1.75)\end{array}$ \\
\hline SCL & $\begin{array}{c}-0.0001 * * * \\
(-4.23)\end{array}$ & $\begin{array}{c}-0.0007 * * * \\
(-3.80)\end{array}$ & $\begin{array}{c}-0.0001 * * * \\
(-2.64)\end{array}$ & $\begin{array}{c}-0.0004 * * * \\
(-3.33)\end{array}$ \\
\hline Trade & $\begin{array}{c}0.369 * * * \\
(4.03)\end{array}$ & $\begin{array}{c}0.182 * * * \\
(2.22)\end{array}$ & $\begin{array}{c}0.057 \\
(0.288)\end{array}$ & $\begin{array}{c}0.0132 \\
(0.26)\end{array}$ \\
\hline Breusch-Pagan Test & $\begin{array}{l}333.07 \\
(0.000)\end{array}$ & $\begin{array}{l}245.67 \\
(0.000)\end{array}$ & $\begin{array}{l}230.67 \\
(0.000)\end{array}$ & $\begin{array}{l}246.26 \\
(0.000)\end{array}$ \\
\hline Hausman Test & $\begin{array}{c}15.86 \\
(0.003)\end{array}$ & $\begin{array}{c}0.92 \\
(0.921)\end{array}$ & $\begin{array}{c}1.90 \\
(0.740)\end{array}$ & $\begin{array}{c}3.911 \\
(0.418)\end{array}$ \\
\hline $\begin{array}{l}\text { Observations } \\
\mathrm{R}^{2}\end{array}$ & $\begin{array}{l}105 \\
0.31\end{array}$ & $\begin{array}{c}90 \\
0.26\end{array}$ & $\begin{array}{l}105 \\
0.59\end{array}$ & $\begin{array}{l}135 \\
0.34\end{array}$ \\
\hline \multicolumn{5}{|c|}{$\begin{array}{l}\text { Note: Figures in the parentheses are t-statistics except for Breusch-Pagan test, Hausman test, which are p- } \\
\text { values. } \\
{ }^{*} \text {, ** and *** indicate } 10 \%, 5 \% \text { and } 1 \% \text { significance level, respectively. } \\
1 \text { includes the SAARC countries, namely Bangladesh, India, Pakistan, and Sri Lanka and selected ASEAN } \\
\text { countries, namely Indonesia, the Philippines, and Thailand. } \\
2 \text { includes the SAARC countries, namely Bangladesh, Pakistan, and Nepal, and ASEAN countries, namely } \\
\text { Cambodia, Indonesia, and Thailand. } \\
3 \text { includes SAARC countries, namely Bangladesh, Pakistan, Nepal, and Sri Lanka and selected ASEAN } \\
\text { countries, namely Cambodia, the Philippines, and Thailand. } \\
4 \text { includes major SAARC countries, namely Bangladesh, India, Pakistan, Nepal, and Sri Lanka and selected } \\
\text { ASEAN countries, namely Cambodia, Indonesia, the Philippines, and Thailand, }\end{array}$} \\
\hline
\end{tabular}


The technique effect shows a positive association with child labor; the result provides substantial evidence to suggest that a one-unit increase in the trade intensity variable brings an $18.23 \%$ increase in child labor. This result is consistent with Kis-Katos' (2006) findings, whereby the real income effect of trade can also increase the aggregate child labor, and the impact of trade on child labor also depends on the techniques of production with varying income levels across the SAARC and ASEAN countries.

The second column in Table 6 reports the results of three of the SAARC countries (Pakistan, Bangladesh and Nepal) and three ASEAN countries (Indonesia, Cambodia and Thailand). The latter is included because, on average, incidents of child labor are higher than in their ASEAN counterparts. The results show that the coefficient of the selection effect is insignificant. However, the sign of the variable indicates that it is positively associated with child labor, which is consistent with the theoretically predicted strategy that a decrease (increase) in the number of firms leads to a decrease (increase) in child labor. The results of the scale effect, on the other hand, contradict the theoretical prediction. The scale effect shows a statistically significant negative relationship between the scale effect and child labor.

\section{Alternative Specification}

In alternate empirical specifications, this study compares the alternative econometric models, with regard to their ability to explain the robustness of the results obtained in the previous section. The alternative specifications are Model-A2 and Model-C2; in the former model, the literacy rate is introduced to represent the educational level and to examine the robustness of other variables. This education variable was ignored in Model-A1, to check the effect of the pure demand-side factors of scale, selection and technique effects, which does not include any interaction terms, and specifies an estimating equation that represents the scale, selection and technique effects in a close economy. Model-C1 is a simple trade induced child labor model, with no trade variables, whereas trade intensity is interacted in Model-A1's variables i.e. scale, selection and technique effects. Model-C2 includes unemployment as an additional variable. The marginal effects of child labor from other factors are also important for understanding the impact of trade, in the given trade and child labor settings. This section briefly summarizes the results of Model-A1, Model-A2, Model-C1 and Model-C2.

In Model-A1 for child labor, responses to the selection, scale, and technique effects are statistically significant at the $10 \%$ level of significance. The coefficient estimates of the scale, and selection effects are statistically significant at the conventional level. Whereas, the coefficient estimate of the technique effect is not statistically significant at conventional levels, although a $95 \%$ level of confidence is a standard level but the response of the technique effect is statistically significant at the $90 \%$ confidence level.

In Model-A2 for child labor, responses to the selection, scale, and technique effects are statistically significant at the $10 \%$ level of significance. Whereas, the coefficient estimate of the variable for education is not statistically significant at any level of significance. The Model A2, with the education variable, generated statistically insignificant estimates for child labor. Strikingly, this analysis finds no significant effect of literacy on child labor reductions. The results obtained from the education variable are not very robust, so, this variable has a trivial effect on the other variables. 
Table 7. Alternative Specification

Dependent Variable: Child Labor

\begin{tabular}{|c|c|c|c|c|}
\hline Model Specification: & $\mathrm{A}_{1}$ & $\mathrm{~A}_{2}$ & $\mathrm{C}_{1}$ & $\mathrm{C}_{2}$ \\
\hline SEL & $\begin{array}{l}-0.007 * * * \\
(-3.21)\end{array}$ & $\begin{array}{l}-0.007 * * * \\
(-2.98)\end{array}$ & & \\
\hline TEC & $\begin{array}{l}-0.0008^{*} \\
(-1.79)\end{array}$ & $\begin{array}{l}-0.001^{*} \\
(-1.70)\end{array}$ & & \\
\hline SCL & $\begin{array}{l}0.0062 \text { *** } \\
(7.56)\end{array}$ & $\begin{array}{l}0.006^{* * * *} \\
(7.38)\end{array}$ & & \\
\hline EDU & & $\begin{array}{l}0.061 \\
(0.62)\end{array}$ & & \\
\hline SELTR & & & $\begin{array}{l}-0.0174 \\
(-0.77)\end{array}$ & $\begin{array}{l}-0.0139 \\
(-0.53)\end{array}$ \\
\hline TECTR & & & $\begin{array}{l}0.00005^{*} \\
(1.86)\end{array}$ & $\begin{array}{l}0.00001 * \\
(1.78)\end{array}$ \\
\hline SCLTR & & & $\begin{array}{l}-0.0004 * * * \\
(-3.44)\end{array}$ & $\begin{array}{l}-0.0005^{* * * *} \\
(-3.43)\end{array}$ \\
\hline UNEP & & & & $\begin{array}{l}-0.0001 \\
(-0.30)\end{array}$ \\
\hline Breusch-Pagan Test & $\begin{array}{l}654.46 \\
(0.000)\end{array}$ & $\begin{array}{l}655.19 \\
(0.000)\end{array}$ & $\begin{array}{l}741.89 \\
(0.000)\end{array}$ & $\begin{array}{l}550.18 \\
(0.000)\end{array}$ \\
\hline Hausman Test & $\begin{array}{l}6.96 \\
(0.073)\end{array}$ & $\begin{array}{l}3.02 \\
(0.554)\end{array}$ & $\begin{array}{l}0.14 \\
(0.86)\end{array}$ & $\begin{array}{l}1.96 \\
(0.743)\end{array}$ \\
\hline $\mathrm{R}^{2}$ Overall & 0.30 & 0.37 & 0.25 & 0.12 \\
\hline
\end{tabular}

Note:

***Significance at the $99 \%$ confidence level.

**Significance at the $95 \%$ confidence level.

*Significance at the $90 \%$ confidence level.

SEL : Country specific number of listed companies per squared kilometer.

SELTR : Selection effect interacted with the openness of trade.

TEC : Net Foreign Factor Income (NFFI) per capita.

TECTR : Technique effect interacted with the openness of trade.

SCL : Gross Domestic Product (GDP) per squared kilometer.

SCLTR : Scale effect interacted with the openness of trade:

EDU : Percentage of the population age 15 and above who can read and write.

UNEP : Share of the labor force that is without work but available for and seeking employment.

sNote: $s l_{i t}=\alpha_{0}+\beta_{1} S E L_{i t}+\beta_{2} S C L_{i t}+\beta_{3} T E C_{i t}+u_{i t} \ldots$ Model $\mathrm{A}_{1}$

$$
\begin{aligned}
& \varsigma l_{i t}=\alpha_{0}+\beta_{1} S E L_{i t}+\beta_{2} S C L_{i t}+\beta_{3} T E C_{i t}+\beta_{4} E d u_{i t}+u_{i t} \ldots \text { Model } \mathrm{A}_{2} \\
& s l_{i t}=\alpha_{0}+\beta_{1} \text { SELTR }_{i t}+\beta_{2} \text { TECTR } i t+\beta_{3} \text { SCLTR }_{i t}+u_{i t} \ldots \text { Model } \mathrm{C}_{1} \\
& \zeta l_{i t}=\alpha_{0}+\alpha_{1} \operatorname{SELTR}_{i t}+\alpha_{2} \text { TECTR }_{i t}+\alpha_{3} \operatorname{SCLTR}_{i t}+\alpha_{4} U N E P_{i t}+u_{i t} \ldots \text { Model } \mathrm{C}_{2}
\end{aligned}
$$

In Model-C1, only the trade-induced effects are estimated. However, and interestingly, the estimates of the selection effect variable are statistically insignificant at the 1, 5 and $10 \%$ levels of significance; the reason of this weak relevance is that the standard error of the trade induced selection effect coefficient is very large, relative to the statistic, so this statistic is unable to give a significant response. The coefficient of selection has an unexpected negative sign, but without significance. It shows that there is no direct effect of the trade-induced variables on child labor; while responses to the scale and technique effects are statistically significant at the $10 \%$ level of significance. 
Model-C1 is extended by including an extra variable, unemployment, to see the effect of the trade induced child labor effect. The new model is Model-C2, and it shows approximately similar results, in term of significance and signs, for the trade-induced effects i.e. the selection, scale, and technique effects. Hence, this new variable has no significant effect on reducing child labor. The coefficient of unemployment is insignificant and opposite to the theoretical explanation. The reason for this unexpected sign and significance is the lack of theoretical support and incongruity for the model, which is checking the trade induced child labor effect by using demand side factors for the demand for child labor, while unemployment in Model-C2 addresses the supply side factors of child labor. That is why the supply side factor is a misfit with the demand side factors. The remaining part of the analysis compares the test results across different groupings of the SAARC and ASEAN countries, for a deeper understanding of the trade-induced effects.

\section{CONCLUSION}

The results of this study suggest that if firms are engaged in the production of heterogonous products, an empirical estimation of the total impact of trade on child labor needs to account for the selection effect, in addition to the scale and technique effects. Clearly, this study is of national and global significance because it highlights the association between the selection effect of trade and child labor. The selection effect is the impact of economic integration with a trade-driven market structure through product differentiation associated with the choice process. The openness of trade not only affects the number of firms in the economy, but also the incidents of child labor across international borders. A theoretical explanation of the selection effect is that, holding the scale and technique effects constant, the trade in differentiated goods induces a trade-related child labor selection effect i.e. the openness to trade implies an access to foreign markets, which leads to a change in the number of domestic firms or in the number of product varieties. The change in the number of firms or product varieties, in turn, brings a change in the demand for child labor. This is called the trade-induced child labor selection effect.

The trade-induced child labor scale effect variables are statistically significant for the functional form, which specifies linearity in the scale variable. These results present regional evidence of the transformation that economic growth has on the reduction of child labor in the SAARC and ASEAN countries, with the emphasis on the role of the trade-induced child labor scale and technique effects. In the context of international trade effects, the evidence suggests that the realization of data substantiates the assertions that trade-driven scale effects play a significant role in decreasing child labor.

With respect to trade intensity, theories suggest that when child labor is confined to domestic borders, the adoption of less laborintensive technology produced abroad substitutes for labor-intensive technologies used domestically, thus resulting in a reduction in child labor in the home market. A second possible justification is that the openness to trade can bring about labor amelioration that is embedded in imported production technology. The diffusion of better techniques of production in the domestic market alleviates child labor. Interestingly, these possibilities are inconsistent with the positive coefficient estimates of trade, which are statistically significant in the models for child labor. The results show that, the coefficient estimates of the trade intensity variable are consistently positive for all specifications.

The concluding part finds that child labor is reducing in the SAARC and ASEAN regions, but it may have a number of informal explanations. Trade-induced effects under the new trade theory can give way to the implementation of a range of strategies to improve compliance. Due to the trade-induced child labor effect, the SAARC and ASEAN countries would no longer need child labor to gain a comparative advantage, because most of the countries in both regions can compete on a more level playing field. Additionally, in consonance with 
Krugman's (1979) framework, this analysis finds that specializing in differentiated products can be a source of trade between countries. Product differentiation requires better labor skills and techniques. Therefore, it nullifies the role of unproductive labor practices (child labor) and the policy implication of the selection effect is subtle. The framework suggests a possible labor amelioration, and the results of this amelioration come in the form of bigger gains for the SAARC and ASEAN countries.

Indeed, trade liberalization improves the earnings opportunities for local citizens of countries and it raises a country's exposure to international competition. As a result, inefficient firms in import-competing industries may be forced out of the competition. Regardless of the long run gains from the re-allocation of resources, in the short run, these arrangements may be a sterilizing factor for child labor treatments. So, it is recommended that trade facilities in SAARC and ASEAN should be encouraged to flourish. Last but not the least, this study proposes that it can be worthwhile to use the trade-induced child labor effect to address the underlying economies that give rise to offending child labor practices. If these countries have easy access to global markets, they would be able to enhance their scales of production and improve their production techniques due to income improvements. The result, of course, is a greater reduction in child labor.

\section{LIMITATIONS OF THE STUDY}

The selection effect is an avenue through which child labor can change following trade liberalization. In particular, if the least-efficient firms are the ones to exit, then the demand for child labor will decrease. Note that the "symmetry" assumption is that all the firms are of the same size and efficiency (it follows that the exit of some would not automatically change child labor). This assumption was made for analytical convenience, but contradicts the empirical fact that every country has a very wide range of firms operating within it.
The empirical literature on the demand side factors of child labor is relatively limited due to the scarcity of reliable data. Unfortunately, it is difficult to obtain firm level data on child labor, which would be beneficial to validate the results, and even the survey's reliability can be uncertain due to resistance from firms to disclose information on their usage of child labor and the wages paid to these unlawful workers. Data on adult labor are widely available, while the data for economically active children with respect to different age groups and occupations are virtually non-existent. Such information is crucial for calculating the trade induced child labor effect. The lack of perfect data hampered this study's ability to determine the trade induced child labor effect. Therefore, there is an evident need for time series data on child labor.

\section{ACKNOWLEDGEMENT}

This work was supported by Ministry of Higher Education, Malaysia and Universiti Malaysia Sarawak [grant numbers Research Acculturation Collaborative Effort RACE/E (3)/1250/2015 (06)].

\section{REFERENCES}

Ab-Rahim, R andB. Tariq, 2016. "The Effect of Trade Openness on Child Labour: Empirical Evidence from Developing Economies". International Journal of Economics \& Management, 10(1), 155-171.

Acaroglu, H., and O. Dagdemir, 2010. "The Effects of Globalization on Child Labor in Developing Countries". Business and Economic Horizons, 2, 37-47.

Akabayashi, H., and G. Psacharopoulos, 1999. "The Trade-Off between Child Labour and Human Capital Formation: A Tanzanian Case Study". The Journal of Development Studies, 35 (5), 120-140.

Alam, S., Rehman, S., and M.S. Butt, 2011. "Trade Liberalization, Environmental Degradation and Sustainable Development in Pakistan". European Journal of Social Sciences, 19(1), 84-96.

Azmat, G., and B. Petrongolo, 2014. "Gender and the Labor Market: What Have We Learned from Field and Lab Experiments?", 
IZA Discussion Paper No.8373. Retrieved from http://www.econstor.eu/bitstream/ 10419/96811/1/dp8135.pdf

Balassa, B., 2013. The Theory of Economic Integration. London: Routledge.

Basu, K., and Z. Tzannatos, 2003. "The Global Child Labour Problem: What Do We Know and What Can We Do?".The World Bank Economic Review, 17 (2), 147-173.

Basu, K., and P.H. Van, 1998. "The Economics of Child Labor". American Economic Review, 88 (3), 412-427.

Bleakley, H., and J. Lin, 2012. "Thick-market Effects and Churning in the Labor Market: Evidence from US Cities". Journal of Urban Economics, 72(2), 87-103.

Brainard, S. L., and D.A. Riker, 1997. "Are US Multinationals Exporting US Jobs?”. NBER Working Paper No. 5958. Cambridge, National Bureau of Economic Study.

Busse, M., and G. Wittwer, 2001. "Do Labour Standards Affect Comparative Advantage? Evidence for Labour-Intensive Goods". World Development, 30(11), 1921-1932.

Casson, M., 2012. Multinationals and World Trade (Routledge Revivals): Vertical Integration and the Division of Labour in World Industries. London: Routledge.

Chan, A., 2003. "Racing to the Bottom: International Trade without a Social Clause". Third World Quarterly, 24 (6), 1011-1028.

Collier, P., and D. Dollar, 2002. Globalization, Growth, and Poverty: Building an Inclusive World Economy. Oxford: Oxford University Press.

Copeland, B. R., and M.S. Taylor, 2001. "International Trade and the Environment: A Framework for Analysis". Working Paper No. w8540. National Bureau of Economic Study.

Eckel, C., and J.P.Neary, 2010. "Multi-Product Firms and Flexible Manufacturing in the Global Economy". The Review of Economic Studies, 77 (1), 188-217.

Edmonds, E. V., 2005. "Child Labour in the Global Economy". The Journal of Economic Perspectives, 19(1), 199-220.

Edmonds, E. V., 2015. "Economic Growth and Child Labor in Low Income Economies". Retrieved from: http://glm-lic.iza.org/ file/view/publications/2015-

0814edmonds_izadraft.pdf

Edmonds, E. V., and N. Pavcnik, 2005a. "Child Labor in the Global Economy". The Journal of Economic Perspectives, 19 (1), 199-220.

Edmonds, E. V., and N. Pavcnik, 2005b. "The Effect of Trade Liberalization on Child Labor". Journal of International Economics, 65 (2), 401-419.

Edmonds, E. V., and N. Pavcnik, 2006. "International Trade and Child Labor: Cross-Country Evidence". Journal of International Economics, 68 (1), 115-140.

Egger, H., P. Egger, and D. Greenaway, 2007. "Intra-Industry Trade with Multinational Firms". European Economic Review, 51(8), 1959-1984.

Estevez, K., 2010. Essays on Child Labour, Productivity, and Trade (Doctoral Thesis). University of Florida, Florida.

Estevez, K., 2011. "Nutritional Efficiency Wages and Child Labour". Economic Modelling, 28(4), 1793-1801.

Estevez, K., and T. Levy, 2014. "Intra-industry Trade and the Demand for Child Labour". International Journal of Economic Theory, 10(3), 275-294.

Feenstra, R. C., 2003. Advanced International Trade: Theory and Evidence. Princeton: Princeton University Press.

Fehr, E., E. Kirchler, A. Weichbold, and S. Gächter, 1998. "When Social Norms Overpower Competition: Gift Exchange in Experimental Labour Markets". Journal of Labour Economics, 16(2), 324-351.

Felbermayr, G. and J. Prat, 2011. "Product Market Regulation, Firm Selection, and Unemployment". Journal of the European Economic Association, 9(2), 278-317.

Fung, K. C., and A. M. Maechler, 2007. "Trade Liberalization and the Environment: The Case of Intra-Industry Trade". The Journal of International Trade \& Economic Development, 16(1), 53-69.

Hamermesh, D. S., 1987. "The Demand for Labour in the Long Run". In O. Ashenfelter and R. Layard, eds., Handbook of Labour Economics.Amsterdam: North-Holland, 429-71.

Hausman, J., B. Hall, and Z. Griliches, 1984. "Econometric Models for Count Data and 
an Application to the Patents-R\&D Relationship". Econometrica, 52, 909-938.

Hindman, H. D., 2009. The World of Child Labor: An Historical and Regional Survey. New York: M. E. Sharpe.

Humphries, J., 2010. Childhood and Child Labour in the British Industrial Revolution. Cambridge: Cambridge University Press.

Karlan, D., and M. Valdivia, 2011. "Teaching Entrepreneurship: Impact of Business Training on Microfinance Clients and Institutions". Review of Economics and Statistics, 93 (2), 510-527.

Kis-Katos, K. and G. Schulze, 2006. "Where Child Labour Supply Finds Its Demand?" Working Paper of Institute for Economic Study. University of Freiburg.

Krugman, P. R., 1979. "Increasing Returns, Monopolistic Competition, and International Trade". Journal of International Economics, 9(4), 469-479.

Krugman, P. R., and A.J. Venables, 1996. "Integration, Specialization, and Adjustment". European Economic Review, 40 (3), 959-967.

Krugman, P. R., 1980. "Scale Economies, Product Differentiation, and the Pattern of Trade". American Economic Review, 70, 950-959.

Kurokawa, Y., 2011. "Is a Skill Intensity Reversal a Mere Theoretical Curiosum? Evidence from the US and Mexico". Economics Letters, 112(2), 151-154.

Kurokawa, Y., 2011. "Variety-Skill Complementarity: A Simple Resolution of the
Trade-Wage Inequality Anomaly". Economic Theory, 46(2), 297-325.

Miles, R. E., C. C. Snow, A. D. Meyer, and H. J. Coleman, 1978. "Organizational Strategy, Structure, and Process". Academy of Management Review, 3 (3), 546-562.

Mukhopadhyay, K., and D. Chakraborty, 2005. "Is Liberalization of Trade Good for the Environment? Evidence from India”. Asia Pacific Development Journal, 12(1), 109.

Neumayer, E., and I. De Soysa, 2005. "Trade Openness, Foreign Direct Investment and Child Labour. World Development, 33(1), 43-63.

Nieboer, H. J., 2011. Slavery as an Industrial System: Ethnological Researches. Cambridge: Cambridge University Press.

Ray, R., 2000. "Analysis of Child Labour in Peru and Pakistan: A Comparative Study". Journal of Population Economics, 13(1), 319.

Solow, R. M., 1956. "A Contribution to the Theory of Economic Growth". The Quarterly Journal of Economics, 70, 65-94.

Tariq, B., and R. Ab-Rahim, 2016. "The Environmental Effects of Intra-Industry Trade in the SAARC Region".International Journal of Business and Society, 17(1), 113130.

Topalova, P., 2010. "Factor Immobility and Regional Impacts of Trade Liberalization: Evidence on Poverty from India". American Economic Journal: Applied Economics, 2(4), 1-41.

Notice: The Journal of Indonesian Economy and Business including the Editors decline all errors and flaws found in this article. Authors are fully responsible for them. 